\title{
HUBUNGAN HARGA DIRI DENGAN KEBIASAAN MEROKOK PADA REMAJA DI DESA MENURAN KECAMATAN BAKI SUKOHARJO
}

\author{
Dinar Ariasti ${ }^{1}$, Iva Puspita Sari ${ }^{2}$
}

\begin{abstract}
Background: Factors that can affect smoking habits in teenagers include the need for self-actualization, pressure or ridicule by peers if not smoking. Pressure in the form of ridicule makes an appreciation of a teenager's self decline and this condition is likely to affect teens to start trying to smoke. When interviewed by several teenagers in the village Menuran Baki Sukoharjo they smoke because follow-friends smoke and feel more acceptable in the association when smoking.

The purpose of this study was to determine the relationship of self esteem concept and smoking habit in teenagers in Menuran Village Baki, Sukoharjo.

The subjects The population in this study were male teenagers who smoked in the village Menuran Baki Sukoharjo, based on preliminary survey

Methods: This research use correlation research design with cross sectional method approach. The data collection tool used is a questionnaire to measure the concept of selfesteem and Smoking Behavior by finding the primary data from Menuran village.

The results of the study: There were $66.67 \%$ of respondents have positive self-esteem concept and $33.33 \%$ of respondents have negative self-concept concept. There are $71.43 \%$ of respondents have mild smoking habit and $4.76 \%$ respondents have smoking habit in level weight. Result of test with Pearson Chi-Square $\alpha=5 \%(0.05)$ got result there is relation of self-esteem concept with smoking habit at teenagers in Village of Menuran District of Baki Sukoharjo with $p=0.001$ so that $p$ value $<0.05$.

The conclusion of this study: There is a relationship of self esteem concept with smoking habit in teenagers of Menuran Village Baki Sukoharjo.
\end{abstract}

Keywords: Self-esteem Concept, Smoking Habit

\section{PENDAHULUAN}

Rokok adalah suatu benda yang berbentuk silinder yang terbuat dari kertas dengan panjang sekitar 120 $\mathrm{mm}$ dan memiliki diameter sekitar 10 $\mathrm{mm}$. Rokok berisi daun-daun tembakau yang telah dicacah. Cara menggunakannya yaitu rokok dibakar pada salah satu ujungnya. Setelah itu biarkan rokok tersebut membara agar asapnya dapat dihirup lewat mulut pada ujung rokok yang lain. Rokok memiliki dua jenis yaitu, rokok berfilter dan rokok tidak berfilter.

Kandungan rokok terdiri dari berbagai macam zat yang beracun seperti, nikotin, tar, insektisida, polycyclic, dan carcinogen yang sebagian zat kimiawi di atas dengan sendirinya mampu memicu penyakit kanker, begitupun dengan tambahan zat lain yang melengkapi rokok yang memperkuat prosesnya (Husaini, 2007).

Para peneliti bahkan berhasil mengungkapkan adanya sekitar 30 zat kimiawi yang mampu memicu penyakit kanker dalam setiap batang rokok. Di antara zat kimiawi yang dianggap paling berbahaya adalah Beta-Naphtylamine dan PAH (Polcyclic Aromatic Hydrocarbon). Para peneliti mengemukakan bahwa keduanya mampu menjadi pencetus datangnya penyakit kanker (Husaini, 2007).

Menurut World Health Organization (WHO, 2009) dalam Kemenkes (2013), persentase penduduk dunia yang mengkonsumsi tembakau adalah $57 \%$ pada penduduk Asia dan Australia, $14 \%$ pada penduduk Eropa Timur dan Uni Soviet, 12\% 
penduduk Amerika, 9\% penduduk Eropa Barat, dan 8\% penduduk Timur Tengah serta Afrika. Sedangkan persentase penduduk yang mengkonsumsi tembakau di Asia Tenggara tersebar di Indonesia sebesar $46.16 \%$, Filipina $16.62 \%$, Vietnam $14.11 \%$, Myanmar $8.73 \%$, Thailand $7.74 \%$, Malaysia $2.90 \%$, Kamboja $2.07 \%$, Singapura $0.39 \%$, dan Brunei $0.04 \%$. Menurut Riskesdas (2013), terdapat $24.3 \%$ perokok aktif yang setiap hari merokok, 5\% perokok kadangkadang, 4\% mantan perokok dan $66.6 \%$ tidak merokok. Hampir $80 \%$ perokok merokok ketika usianya belum mencapai 19 tahun. Menurut Kemenkes (2014) yang dikutip Wijayanti (2016), umumnya orang mulai merokok sejak muda dan tidak tahu risiko mengenai bahaya adiktif rokok.

Faktor-faktor yang berperan dalam perilaku merokok pada remaja disampaikan dalam penelitian Wulan (2012) dengan judul faktor psikologis yang mempengaruhi perilaku merokok pada remaja dengan hasil faktor pembentukan image dari merokok bagi remaja, $8 \%$ dari responden menyatakan ingin memiliki image terlihat dewasa dengan merokok dan $4 \%$ menyatakan ingin terlihat "gaya". Sedangkan faktor afektif dari rokok yaitu, 5.3\% responden menganggap rokok memberikan kenikmatan dan 4\% menganggap rokok memberikan perasaan tenang bagi mereka.

Hal ini juga seperti yang disampaikan oleh Abdullah (2014) dalam penelitiannya yang berjudul hubungan perilaku merokok dengan harga diri remaja putra di SMK Muhammadiyah 4 Jakarta. Populasi dalam penelitian ini adalah remaja putra yang merokok di SMK Muhammadiyah 4 Jakarta pada tahun 2014. Hasil penelitian menyatakan faktor sosial (0.043), faktor psikososial (0.005), dan pada faktor genetik (0.027) dengan harga diri < a (0.05), sehingga dapat disimpulkan terdapat hubungan perilaku merokok dengan harga diri remaja putra di SMK Muhammadiyah 4 Jakarta.

Menurut Wijayanti (2016), tingkat penyebaran perokok paling tinggi terdapat pada usia anak atau remaja. Undang-undang nomor 23 tahun 2002 menyatakan anak adalah seseorang yang belum berusia 18 tahun. Karena usia anakanak maka menimbulkan beberapa bahaya yang terjadi pada remaja perokok yang biasanya masih labil yaitu cenderung untuk mencoba zat adiktif lain dan narkoba. Faktor yang dapat mempengaruhi kebiasaan merokok pada remaja diantaranya adalah pola asuh orang tua, pengaruh teman sebaya yang merokok, tayangan iklan rokok dan kebutuhan aktualisasi diri, tekanan atau ejekan oleh teman sebaya jika tidak merokok. Tekanan dalam bentuk ejekan membuat keberhargaan tentang diri seorang remaja menurun dan kondisi ini cenderung akan mempengaruhi remaja untuk mulai mencoba rokok sampai menjadi perokok pemula dan akhirnya menjadi pencandu rokok. Sebagaimana yang dikemukakan oleh Azkiyati (2012), latar belakang remaja mulai merokok berkaitan dengan adanya krisis aspek psikososial pada masa perkembangan remaja, yaitu masa ketika remaja sedang mencari jati diri. Sebagai penggambaran sejauhmana individu menilai dirinya sendiri sebagai orang yang memiliki kemampuan, berharga dan berkompeten, atau penilaian pribadi terhadap hasil yang dicapai dengan menganalisis seberapa banyak kesesuaian tingkah laku dengan ideal diri dinamakan dengan self esteem atau yang lebih sering dikenal dengan harga diri (Wijayanti, 2016). Seperti penelitian yang dilakukan oleh Kasdianto dan Rizal (2016) yang berjudul hubungan 
harga diri dengan perilaku merokok pada remaja laki-laki di SMK PGRI 1 Kediri dengan populasi penelitian remaja laki-laki usia 16 tahun yang merokok di SMK PGRI 1 Kediri yang berjumlah 148 responden. Diperoleh hasil penelitian ada hubungan antara harga diri dengan perilaku merokok pada remaja laki-laki di SMK PGRI 1 Kediri dengan hasil $p$ value 0.05 . Begitu pula penelitian yang dilakukan oleh Prasetya (2014) dengan judul hubungan harga diri dengan perilaku merokok pada mahasiswi UKSW, hasil penelitian menunjukkan bahwa mayoritas responden merupakan bukan perokok harian, tipe perokok ringan, dan harga diri positif. Penelitian ini menunjukkan adanya hubungan yang bermakna antara perilaku merokok dengan harga diri ( $p$ value $=0.025$ ).

Berdasarkan data yang diperoleh dengan wawancara pada beberapa remaja di Desa Menuran, Baki, diperoleh informasi bahwa mereka ikut-ikutan merokok karena dianggota keluarga ada yang merokok atau teman sebaya yang merokok. Saat merokok mereka lebih diterima dalam pergaulan, beberapa pemahaman remaja di Desa Menuran Baki tentang merokok masih kurang tepat sehingga perlu dilakukan penelitian tentang hubungan antara kebiasaan merokok dengan konsep harga diri pada remaja di Desa Menuran Baki Sukoharjo.

Berdasarkan uraian di atas maka penulis tertarik untuk melakukan penelitian dengan judul hubungan antara konsep harga diri dengan kebiasaan merokok pada remaja di Desa Menuran Baki Sukoharjo.

Penelitian ini merupakan replika dari penelitian yang dilakukan oleh Kasdianto dan Rizal (2016) dengan judul "Hubungan Harga Diri dengan Perilaku Merokok pada Remaja Laki-Laki di SMK PGRI 1 Kediri”. Perbedaan penelitian adalah lokasi penelitian dimana pada penelitian di atas dilaksanakan di lingkungan sekolah sedangkan penelitian ini dilakukan dilingkungan masyarakat. Faktor lingkungan juga dapat menjadi salah satu faktor pendukung terjadinya kebiasaan merokok.

\section{TUJUAN PENELITIAN}

Tujuan umum untuk mengetahui hubungan antara konsep harga diri dengan kebiasaan merokok pada remaja di desa Menuran, Baki, Sukoharjo.

Tujuan khusus untuk mengetahui tentang gambaran harga diri dan gambaran kebiasaan merokok pada remaja di desa Menuran, Baki Sukoharjo.

\section{DESAIN PENELITIAN}

Penelitian ini merupakan penelitian analitik dengan desain korelasi untuk mengetahui hubungan konsep harga diri sebagai variabel bebas (independent variabel) dengan kebiasaan merokok sebagai variabel terikat (dependent variabel) remaja di Desa Menuran, Baki Sukoharjo.

\section{POPULASI, SAMPEL DAN TEKNIK SAMPLING}

Populasi pada penelitian ini adalah seluruh remaja yang merokok berusia 12-21 tahun di Desa Menuran, Baki, Sukoharjo, yang berjumlah 42 orang. Dalam penelitian ini, peneliti menggunakan teknik sampling jenuh atau seluruh anggota populasi dijadikan sampel, mengingat jumlah populasi hanya sedikit, sehingga sampel penelitian adalah seluruh remaja merokok berusia 12-21 tahun di Desa Menuran Baki Sukoharjo.

Dalam penelitian ini, alat pengumpulan data yang digunakan adalah kuesioner dan analisa bivariat menggunakan uji Pearson Correlation dengan program SPSS seri 18. 
HASIL PENELITIAN

Penelitian dilakukan di Desa Menuran Kecamatan Baki Kabupaten Sukoharjo dengan jumlah responden sebanyak 42 remaja.

Di bawah ini akan dipaparkan hasil penelitian tentang hubungan konsep harga diri dengan kebiasaan merokok di desa Menuran Kecamatan Baki Kabupaten Sukoharjo.

Tabel 1.

Distribusi Frekuensi Responden Berdasarkan Umur

\begin{tabular}{ccc}
\hline Kelompok Umur & $\mathrm{f}$ & $\%$ \\
\hline $13-15$ & 9 & 21.42 \\
$16-18$ & 22 & 52.38 \\
$19-21$ & 11 & 26.20 \\
Tingkat Pendidikan & & \\
SMP & 10 & 23.80 \\
SMA & 23 & 54.77 \\
PT & 9 & 21.43 \\
\hline
\end{tabular}

Dari tabel di atas diperoleh informasi bahwa sebagian besar responden berjumlah 22 responden (52.38\%) berada pada kelompok umur 16-18 tahun dan jumlah responden paling sedikit 9 responden (21.42\%) berada pada kelompok umur 13-15 tahun.

Tabel 2.

Distribusi Frekuensi Konsep Harga Diri pada Remaja di

Desa Menuran Kecamatan Baki Kabupaten Sukoharjo

\begin{tabular}{ccc}
\hline $\begin{array}{c}\text { Harga Diri } \\
\text { pada Remaja }\end{array}$ & $\mathrm{f}$ & $\%$ \\
\hline Positif & 28 & 66.67 \\
Negatif & 14 & 33.33 \\
\hline Jumlah & 42 & 100 \\
\hline
\end{tabular}

Dari tabel di atas ditemukan ada 28 responden (66.67\%) atau sebagian besar responden mempunyai konsep harga diri yang positif dan
14 responden (33.33\%) mempunyai konsep harga diri yang negatif.

Tabel 3.

Distribusi Frekuensi Kebiasaan

Merokok pada Remaja di Desa Menuran Kecamatan Baki Kabupaten Sukoharjo

\begin{tabular}{ccc}
\hline $\begin{array}{c}\text { Kebiasaan } \\
\text { Merokok }\end{array}$ & $\mathrm{f}$ & $\%$ \\
\hline Ringan & 30 & 71.43 \\
Sedang & 10 & 23.81 \\
Berat & 2 & 4.76 \\
\hline Jumlah & 42 & 100 \\
\hline
\end{tabular}

Dari tabel di atas ditemukan sebagian besar responden sejumlah 30 orang $(71.43 \%)$ mempunyai kebiasaan merokok tingkat ringan dengan menghabiskan rokok minimal 1 batang sampai 10 batang perharinya dan 2 responden $(4.76 \%)$ mempunyai kebiasaan merokok dalam tingkat berat dengan menghabiskan lebih dari 2 bungkus rokok perharinya.

Tabel 4

Tabulasi Silang Hubungan Konsep Harga Diri dengan Kebiasaan Merokok pada Remaja di Desa Menuran Baki Sukoharjo

\begin{tabular}{ccccc}
\hline \multirow{2}{*}{$\begin{array}{c}\text { Harga } \\
\text { Diri }\end{array}$} & \multicolumn{3}{c}{ Kebiasaan Merokok } & \\
\cline { 2 - 4 } & Ringan & Sedang & Berat & Jumlah \\
\hline Positif & 25 & 3 & 0 & 28 \\
Negatif & 5 & 7 & 2 & 14 \\
\hline Jumlah & 30 & 10 & 2 & 42 \\
\hline
\end{tabular}

Dari tabel di atas peneliti menemukan bahwa :

1. Terdapat responden dengan konsep harga diri positif sebagian besar memiliki kebiasaan merokok ringan sejumlah 25 responden dan sedang sebanyak 3 responden. 
2. Terdapat 5 responden dengan konsep harga diri negatif mempunyai kebiasaan merokok ringan, 7 responden mempunyai kebiasaan merokok sedang dan 2 responden mempunyai kebiasaan merokok berat.

Dari hasil penelitian hubungan konsep harga diri dengan kebiasaan merokok pada remaja di Desa Menuran Kecamatan Baki Sukoharjo diperoleh hasil uji dengan Pearson Chi-Square program SPSS versi 18.0 dengan $\alpha=5 \%$ (0.05) diperoleh $p=0.001$ sehingga nilai $p<0.05$, yang berarti $\mathrm{Ho}$ ditolak dan $\mathrm{Ha}$ diterima, sehingga dapat ditarik kesimpulan bahwa ada hubungan konsep harga diri dengan kebiasaan merokok pada remaja di Desa Menuran Kecamatan Baki Sukoharjo.

\section{PEMBAHASAN}

Dari hasil tabel 2 dapat dicermati bahwa dari tabel di atas ditemukan ada 28 responden $(66.67 \%)$ atau sebagian besar responden mempunyai konsep harga diri yang positif dan 14 responden (33.33\%) mempunyai konsep harga diri yang negatif. Responden dengan harga diri yang positif mengungkapkan bahwa mereka merasa percaya diri dan bangga terhadap dirinya sendiri dan mudah menyesuaikan diri dengan lingkungan. Sebagian besar responden menjadi anggota karangtaruna dan aktif di kegiatankegiatan yang diselenggarakan oleh karangtaruna. Remaja di desa Menuran sering berkumpul karena banyak kegiatan diselenggarakan oleh karangtaruna. Faktor lingkungan menjadi salah satu faktor yang mempunyai peranan dalam pembentukan harga diri pada remaja, hal ini seperti yang diungkapkan oleh Azkiyati (2012), bahwa lingkungan memberikan dampak besar kepada remaja melalui hubungan yang baik antara remaja dengan orang tua, teman sebaya, dan lingkungan sekitar. Lingkungan yang membuat remaja merasa diterima, dihargai, dan dihormati, akan menjadikan remaja merasa bahwa dirinya bernilai untuk dirinya sendiri dan orang lain.

Pengaruh teman sebaya pada harga diri remaja juga sangat besar karena remaja cenderung mempunyai lebih banyak waktu untuk bergaul dengan teman sebayanya, saling berinteraksi dan melakukan kegiatan bersama. Dalam lingkungan sebaya ini, remaja berusaha menemukan konsep dirinya. Seperti yang diungkapkan Sarwono (2013), bahwa di lingkungan sebaya remaja dinilai oleh teman sebayanya tanpa memperdulikan sanksi-sanksi orang dewasa. Kelompok sebaya memberikan lingkungan, yaitu dunia tempat remaja dapat melakukan sosialisasi di mana nilai yang berlaku bukanlah nilai yang ditetapkan oleh orang dewasa, melainkan oleh teman seusianya. Inilah letak berbahayanya bagi teman sebaya memainkan peran yang signifikan dalam kehidupan remaja.

Tahap perkembangan seseorang juga mempengaruhi konsep diri, hal ini dapat terlihat dari tabel 1 bahwa sebagian besar responden berjumlah 22 responden (52.38\%) berada pada kelompok umur 16-18 tahun. Menurut Mubarak (2009), pada masa ini remaja mampu melewati masa sebelumnya dengan baik, dapat menerima kodratnya dengan baik, baik laki-laki atau perempuan. Mereka juga merasa bangga karena tubuh mereka yang dianggap menentukan harga diri. Umumnya kematangan pada fisik sudah tercapai, namun kematangan psikologisnya belum tercapai penuh. Sehingga para remaja mudah terpengaruh ajakan orang lain untuk melakukan perbuatan yang tidak baik. 
Hasil penelitian tentang perilaku merokok di Desa Menuran Baki Sukoharjo seperti yang tercantum dalam tabel 3 ditemukan sebagian besar responden sejumlah 30 orang (71.43\%) mempunyai kebiasaan merokok tingkat ringan dengan menghabiskan rokok minimal 1 batang sampai 10 batang perharinya dan 2 responden $(4.76 \%)$ mempunyai kebiasaan merokok dalam tingkat berat dengan menghabiskan lebih dari 2 bungkus rokok perharinya. Perilaku merokok pada remaja di Desa Menuran Baki Sukoharjo cukup tinggi, hal ini terlihat saat kegiatan-kegiatan remaja berlangsung hampir semua remaja terlihat merokok. Beberapa remaja yang merokok di desa Menuran tersebut mereka dimungkinkan ikut-ikutan merokok karena dianggota keluarga ada yang merokok atau teman sebaya yang merokok. Saat merokok mereka merasa lebih diterima dalam pergaulan sehingga banyak yang memilih tetap merokok walaupun mengetahui dampak merugikan yang disebabkan oleh merokok. Hal ini seperti yang diungkapkan oleh Aula (2010), bahwa faktor terbesar dari kebiasaan merokok adalah faktor sosial atau lingkungan. Terkait hal itu, tentu telah diketahui bahwa karakter seseorang banyak dibentuk oleh lingkungan sekitar, baik keluarga, tetangga, ataupun teman pergaulan. Hal ini sesuai dengan penelitian yang dilakukan Santoso (2008), yang menunjukkan bahwa faktor teman sebaya memberikan pengaruh paling dominan mempengaruhi perilaku merokok remaja di desa Godean Tamantirto Kasihan Bantul dengan nilai signifikansi $0.015<0.05$.

Dari hasil penelitian hubungan konsep harga diri dengan kebiasaan merokok pada remaja di Desa Menuran Kecamatan Baki Sukoharjo diperoleh hasil uji dengan Pearson Chi-Square program SPSS versi 18.0 dengan $\alpha$ $=5 \%(0.05)$ diperoleh $p=0.001$ sehingga nilai $p<0.05$, yang berarti Ho ditolak dan $\mathrm{Ha}$ diterima, sehingga dapat ditarik kesimpulan bahwa ada hubungan konsep harga diri dengan kebiasaan merokok pada remaja di Desa Menuran Kecamatan Baki Sukoharjo.

Hasil analisa hubungan antara konsep Harga diri dengan perilaku merokok pada remaja di Desa Menuran Kecamatan Baki Sukoharjo menyimpulkan bahwa responden yang memiliki harga diri yang positif sebagian besar memiliki kebiasaan merokok dalam taraf yang masih ringan sedangkan yang memiliki konsep harga diri negatif mempunyai kebiasaan merokok dari ringan, sedang sampai berat. Kebiasaan merokok merupakan salah satu perilaku berisiko buruk terhadap kesehatan karena penyakit yang ditimbulkan. Remaja mempunyai keinginan yang besar untuk mencoba-coba suatu perilaku, mengikuti perkembangan zaman dan melakukan tindakan yang buruk untuk bersenang-senang termasuk kebiasaan merokok. Remaja yang memiliki harga diri positif memandang dirinya baik karena penilaian yang remaja dapat dari orang lain, merasa memiliki lebih banyak kelebihan dibandingkan dengan orang lain serta menilai dirinya secara keseluruhan adalah orang yang berhasil. Memiliki perasaan yang positif akan dirinya membuat remaja mampu menerima dirinya apa adanya, merawat dan menjaga dirinya dengan baik sehingga kebiasaan merokok dapat dikurangi. Sedangkan kebalikannya remaja yang memiliki harga diri negatif mempunyai ketakutan dianggap tidak cakap, takut dianggap remeh dan disingkirkan dari pergaulan. Mereka tidak percaya diri untuk membuat keputusan tentang perilaku yang akan dilakukan. Hal ini senada 
dengan hasil penelitian yang dilakukan Fatmawati (2012), yang menunjukkan bahwa terjadi hubungan yang negatif dan signifikan antara tingkat harga diri dan tingkat intensi merokok pada siswa SMAN Plaosan sehingga dapat diindentifikasikan semakin tinggi tingkat harga diri maka semakin rendah intensi merokoknya begitu pula sebaliknya bila rendah tingkat harga diri maka intensi merokok semakin tinggi dengan koefisien korelasi $(R)$ sebesar 0.617 , dengan $p=0.000 \quad(p<0.01)$ yang menunjukkan bahwa korelasi kedua variabel adalah kuat, dengan jumlah responden 61 .

Kepercayaan diri juga merupakan salah satu komponen dari pembentukan harga diri. Kepercayaan diri membuat individu dapat menentukan arah dan tujuan hidup serta mempunyai keyakinan akan kemampuan yang dimilikinya. Remaja saat dihadapkan situasi yang belum pernah terjadi maka akan timbul rasa cemas, takut dan kurang percaya diri saat menghadapi situasi tersebut, situasi seperti ini dapat menyebabkan remaja memilih untuk merokok. Hal ini sesuai dengan penelitian yang dilakukan oleh Sofia dan Kuswardani (2009), dengan hasil yang menunjukkan terdapat hubungan negatif dan sangat signifikan antara kepercayaan diri dan perilaku merokok pada remaja SMA Muhammadiyah II Surakarta dengan koefisien korelasi sebesar 0.453 dengan $p=0.000 \quad(p<0.01)$. Semakin tinggi kepercayaan diri remaja maka semakin rendah perilaku merokok begitu pula sebaliknya semakin rendah kepercayaan diri semakin tinggi perilaku merokok.

Harga diri merupakan salah satu komponen dari konsep diri, konsep diri yang positif atau negatif tergantung dari penilaian remaja itu sendiri, remaja yang mempunyai konsep diri yang positif cenderung lebih percaya diri sehingga perilaku menjadi lebih produktif. Sementara itu remaja dengan konsep diri negatif biasanya akan menjadi remaja yang rendah diri, perasaan rendah diri ini menyebabkan remaja menjadi tidak puas dengan konsep dirinya sehingga perilaku yang ditampilkan cenderung negatif. Hal ini dibuktikan dengan penelitian yang dilakukan oleh Hasanah (2009), dengan hasil analisis menunjukkan adanya hubungan negatif yang signifikan antara konsep diri dan sikap terhadap perilaku merokok. Hasil analisis yang menyatakan adanya hubungan negatif kedua variabel yang berarti tinggi rendahnya atau baik buruknya konsep diri mempengaruhi sikap terhadap perilaku merokok pada subjek penelitian yang ditunjukkan oleh nilai koefisien korelasi sebesar -0.347 dengan $p=0.001$ atau $(p<$ $0.05)$.

\section{KESIMPULAN}

Dari hasil penelitian hubungan konsep harga diri dengan Kebiasaan merokok pada remaja di Desa Menuran Kecamatan Baki Sukoharjo diperoleh hasil uji dengan Pearson Chi-Square program SPSS versi 18.0 dengan $\alpha$ $=5 \%(0.05)$ diperoleh $p=0.001$ sehingga nilai $p<0.05$, yang berarti Ho ditolak dan $\mathrm{Ha}$ diterima, sehingga dapat ditarik kesimpulan bahwa ada hubungan antara konsep harga diri dengan kebiasaan merokok pada remaja di Desa Menuran Kecamatan Baki Sukoharjo.

\section{SARAN}

1. Dari hasil penelitian didapatkan hasil ada hubungan antara konsep harga diri dengan kebiasaan merokok pada warga di Desa Menuran Kecamatan Baki Sukoharjo, dengan hasil tersebut diharapkan para remaja 
dapat meningkatkan harga diri positif dengan mengikuti kegiatan-kegiatan yang positif dan mengurangi kebiasaan merokok.

2. Diharapkan para tokoh masyarakat dan orangtua dapat memberikan contoh yang baik dengan tidak melakukan kebiasaan merokok dihadapan anak agar anak terutama remaja yang masih labil tidak mencontoh tindakan tersebut.

3. Diharapkan peneliti selanjutnya dapat melakukan penelitian yang berkaitan dengan konsep harga diri dan kebiasaan merokok dilihat dari faktor-faktor yang lain seperti jenis kelamin, tingkat pendidikan, pola asuh orangtua dan lingkungan.

\section{DAFTAR PUSTAKA}

Abdullah, M. 2014. "Hubungan Perilaku Merokok dengan Harga Diri Remaja Putra di SMK Muhammadiyah Jakarta". Universitas Esa Unggul. Jakarta. Diakses pada tanggal 2 November 2017.

Aula, L.E. 2010. Stop Merokok. Gara IImu, Jogjakarta.

Azkiyati, A.M. 2012. "Hubungan Perilaku Merokok dengan Harga Diri Remaja Laki-Laki yang Merokok di SMK Putra Bangsa". Universitas Indonesia. Diakses pada tanggal 28 September 2017.

Fatmawati, A. 2012. "Hubungan Harga Diri Dengan Intensi Merokok Pada Siswa SMAN 1 Plaosan Kabupaten Magetan". Fakultas Psikologi Universitas Islam Negeri (UIN) Maulana Malik Ibrahim Malang. Diakses tanggal 28 April 2018

Hasanah, U. 2009. "Hubungan antara Konsep Harga Diri dan Sikap terhadap Perilaku Merokok pada Remaja Perokok". Fakultas Psikologi
UII. Diakses pada tanggal 28 April 2018.

Husaini, A. 2007. Tobat Merokok. Pustaka Iman, Jakarta.

Kasdianto dan K.A. Rizal. 2016. "Hubungan Harga Diri dengan Perilaku Merokok pada Remaja Laki-laki di SMK PGRI 1 Kediri". Universitas Brawijaya Malang. Diakses tanggal 2 November 2017.

Kementerian Kesehatan RI. 2013. Riset Kesehatan Dasar (Riskesdas). Badan Penelitian dan Pengembangan, Jakarta.

Mubarak, W.I. 2009. Sosiologi untuk Keperawatan : Pengantar dan Teori. Salemba Medika, Jakarta.

Prasetya B.E.A., dan J.T. Purnomo. 2014. "Hubungan Harga Diri dengan Perilaku Merokok pada Mahasiswi UKSW". Program Studi Psikologi FPSI-UKSW. Diakses tanggal 20 Februari 2018.

Santoso, E.B. 2008. "Faktor-Faktor Lingkungan yang

Mempengaruhi Perilaku Merokok Remaja di Desa Godegan Tamantirto Kasihan Bantul".

http://thesis.umy.ac.id/data publik/t9747. Diakses 28 April 2018.

Sarwono, S.W. 2013. Psikologi Remaja. PT. Rajagrafindo Persada, Depok.

Sofia, H.A. dan I. Kuswardani. Hubungan antara Kepercayaan Diri dengan Perilaku Merokok pada Remaja. Jurnal Psikohumanika Volume 2, Nomer 2. Diakses tanggal 28 April 2018.

Wijayanti, A. 2016. "Hubungan Harga Diri dengan Perilaku Merokok pada Remaja LakiLaki di SMPN 2 Gamping". Repository Stikes Jendral A. Yani Yogyakarta. Volume 1. 
Diakses pada tanggal 28 September 2017.

Wulan, D.K. 2012. 'Faktor Psikologi yang Mempengaruhi Perilaku Merokok pada Remaja". Jurnal Humaniora. Volume 3. Diakses pada tanggal 28 September 2017.

${ }^{1}$ Dosen Akper Panti Kosala

Surakarta

${ }^{2}$ Mahasiswa Akper Panti Kosala

Surakarta 
"KOSALA" JIK Vol. 6 No. 1 Mei 2018 